\title{
REPRODUCTIVE TOXICITY OF METALS IN MEN
}

\author{
Alica PIZENT, Blanka TARIBA, and Tanja ŽIVKOVIĆ \\ Institute for Medical Research and Occupational Health, Zagreb, Croatia \\ Received in September 2011 \\ CrossChecked in September 2011 \\ Accepted in January 2012
}

\begin{abstract}
A combination of genetic, environmental and lifestyle factors contributes to adverse effects on the reproductive health in men. Metals are pervasive in food, water, air, tobacco smoke, and alcoholic beverages. Experimental studies suggest that many metals have adverse effects on the male reproductive function. However, information about reproductive effects of human exposure to metals is scarce and/or inconsistent. This review summarises the information from epidemiological studies of the effects of metal exposure on reproductive function in men. Factors capable of affecting these relationships were identified and discussed. A particular attention is given to the studies considering influence of concomitant exposure to various metals.

These studies have generally confirmed that even moderate- to low-level exposure to lead affects certain reproductive parameters, and that exposure to cadmium affects the prostate function and serum testosterone levels. Adverse effects of mercury, manganese, chromium and arsenic on semen quality and altered serum hormone are less well documented. There is no clear evidence that boron exposure may impair reproductive health in men. Only a few studies have investigated reproductive effects of concomitant exposure to several metals and controlled for potential confounders. Future studies should consider the contribution of combined exposure to various metals and/or other factors that may influence individual susceptibility to reproductive health impairment in men.
\end{abstract}

KEY WORDS: human semen quality, metals, metalloids, metal interactions, sex hormones

In 1992, a meta-analysis of data from international literature by Carlsen et al. (1) indicated a significant deterioration in the reproductive health of otherwise normal men in many countries over the period 1938 to 1990 . It prompted other researchers to evaluate their own data. Several studies established an increasing incidence of various abnormalities of the human reproductive system, including a decreased sperm count and an increased incidence of testicular and prostate cancer (2-7), but also great differences among countries and different locations within a country. This has triggered an increasing interest in the possible causes of these abnormalities and factors that contribute to this deterioration and the geographical differences, including environmental and lifestyle factors (8-13).
Metals are everywhere, in food, dietary supplements, water, air, alcoholic drinks, and tobacco. Cigarette smoke contains about 30 metals, of which cadmium, arsenic, and lead are in the highest concentrations, and cadmium body burden in smokers is about double that of non-smokers (14). Alcoholic beverages including wine can be contaminated with metals in concentrations exceeding the allowable limits and causing toxic effects, particularly in heavy drinkers (15-17).

Most reports on the reproductive toxicity of metals are from experimental animal studies, which usually involve high-dose and/or short-term exposure not applicable to common human exposure situations. The human male has a relatively low fertility potential compared with other mammals and is much more 
susceptible to metal toxicity. Therefore, epidemiological studies are needed to validate the effects identified in experimental models. Data on reproductive toxicity in men are scanty for most metals (18-22), and usually limited by inadequate controls and adjustments for the influence of potentially confounding variables.

The aim of this review is to provide a summary of epidemiological research of the effects of metal exposure on reproductive health in men, and particular attention is given to the studies considering the combined influence of several metals and lifestyle factors (e.g., smoking habits and alcohol consumption). We will also discuss other factors that can modify metal status and its effects on the reproductive function in men.

\section{SOURCES OF METAL EXPOSURE}

Men are inevitably exposed to metals due to their ubiquity in nature, wide use in industry and long-term persistence in the environment. The information on the most important occupational and environmental sources of metal exposure has mainly been collected from the toxicological profiles issued by the Agency for Toxic Substances and Disease Registry (ATSDR) (23-29), unless stated otherwise.

Lead is used for ammunition, batteries, solder, and X-ray shields. Sources of occupational exposure include lead mining, refining, smelting, construction work, paint removal, demolition, maintenance of bridges and water towers, car repair, and recycling. Environmental lead exposure has dropped in recent decades thanks to the dominant use of unleaded petrol and the ban of lead-based paint and lead solder in food cans. The general population can be exposed to lead in food and drinks, including lead-contaminated folk remedies (30-32), drinking water (33), and wine (1516). Strongly acidic beverages (such as wine, fruit juices, and soft drinks) and food can be contaminated with lead if stored or served in leaded crystal glassware or lead-glazed ceramics.

Cadmium is used in the production of nickelcadmium batteries, pigments (bright yellow, orange, red, and maroon dyes), ceramics, plastic stabilisers, and fertilisers. Increased production of $\mathrm{CdSe} / \mathrm{CdTe}$ based photovoltaic solar cells for alternative energy production and the use of $\mathrm{CdSe} / \mathrm{CdTe}$ in nanomaterials for biological applications in the past decades may have contributed to increased human exposure to cadmium (34). Cigarette smoke is one of the most important sources of cadmium exposure in the general non-occupationally exposed population. In nonsmokers, the main source of cadmium is food, particularly cereals such as rice and wheat, green leafy vegetables, potato, and offal products such as liver and kidney.

Mercury exists in several forms. Metallic mercury is used for the extraction of gold and silver from ores, in the production of chlorine gas and caustic soda, in thermometers, barometers, fluorescent light bulbs, and some electrical and electronic switches, as a component in dental amalgam fillings, and in some herbal or religious remedies. Organic and inorganic compounds of mercury are used as catalysts for polyurethane and other polymer production, in the production of fungicides, pigments, cosmetics (e.g. skin whitening cream and mascara), and pharmaceuticals (e.g. vaccine preservatives such as thiomersal and eye drops). The most common organic compound of mercury is methylmercury $(\mathrm{MeHg})$. The general population is exposed to $\mathrm{MeHg}$ mainly through diet, especially through freshwater (e.g. pike and bass) and marine (e.g. shark, swordfish, barracuda, large tuna) fish.

Organic manganese compounds are used in the production of pesticides, whereas methylcyclopentadienyl manganese tricarbonyl (MMT) is used as a petrol additive. Manganese can also be found in grains and cereals, and in high amounts in tea.

Arsenic is a metalloid. Inorganic arsenic compounds are highly toxic, whereas organic compounds are harmless. Elemental arsenic is used as an alloying element in ammunition and solders. Inorganic arsenic is used to preserve wood. The use of inorganic arsenic for pesticides is no longer permitted. Organic compounds of arsenic are used as herbicides and as antimicrobial additives for animal and poultry feed. Fish and seafood may contain high levels of harmless organic forms of arsenic. Diet is generally the main source of arsenic. The general population may be exposed to high levels of inorganic arsenic in drinking water from the areas that contain high natural levels of arsenic in rock, e.g. several localities in East Croatia (35).

Chromium is present in several forms. Metal chromium (0) is used in steel production, whereas chromium (VI) and chromium (III) are used for chrome plating, dyes and pigments, leather tanning, and wood preserving. Chromium (VI) compounds are more toxic than chromium (III) compounds. Chromium (III) occurs naturally in the environment and is an essential nutrient, present in food. 
Boron in the form of borates or boric acid is widely used in the production of sodium perborate bleaches, soaps and detergents, insulation materials, fiberglass, borosilicate glass, fire retardants, wood preservatives, adhesives, pesticides, soldering and welding fluxes, and cosmetics. As an antiseptic and antibacterial compound, boric acid can be used to wash the eyes and treat yeast and fungal infections. Boron can mainly be found in nuts, fruits, and vegetables.

\section{FACTORS INFLUENCING HEALTH OUTCOMES OF HUMAN EXPOSURE TO METALS}

Men are usually exposed to many metals and other agents that act together resulting in adverse health effects or increased sensitivity to these effects. It is often difficult to correlate specific metal exposure to specific effect because of the complexity of these relationships. Many factors can influence health outcomes of human exposure to metals.

Some of them are metal speciation (chemical form), dose, timing, routes and duration of exposure, dose-response relationship, bioavailability, and distribution and accumulation of metals in various organs. Response to metal exposure also depends on the age, sex, health status, dietary habits, use of medications and/or supplements, physical activity, and concomitant exposure to other metals and/or chemicals (36-37).

Metals can interact additively, synergistically, or antagonistically and affect each other's absorption, distribution, and excretion. Toxic metals can interfere with the metabolism of essential metals and reduce their concentration in the organism or decrease their bioavailability $(36,38-40)$. For example, competition between lead and/or cadmium and zinc for the same binding sites in enzymes, proteins, and transporters, can change enzyme activity, affect the structure and/or function of cell membranes, induce oxidative stress and apoptosis, and inhibit DNA and RNA synthesis and repair. This may have serious consequences on cell growth, development, and differentiation. On the other hand, essential metals (e.g., zinc and selenium) may decrease the absorption and retention of toxic metals and prevent their toxic effects. Moreover, metals have a significant role in the antioxidant system, adaptive response, and genetic repair system. Therefore, the interaction between various toxic and/or essential metals could be particularly important for the final health outcomes of metal exposure. These interactions contribute to interindividual differences in susceptibility to adverse effects of metals in men (36).

One of the factors responsible for these differences in susceptibility to metal exposure between individuals living in the same or similar environments is genetic polymorphism. Several recent attempts to investigate the influence of genetic polymorphisms on metal metabolism have identified varieties in genetic coding for proteins involved in metal absorption, retention, biotransformation, transport, and storage, for proteins comprising plasma membrane ion channels, and for enzymes protecting against oxidative stress. However, only a few studies have assessed the potential effects of these polymorphisms on the relationship between metal exposure and health outcomes in men (reviewed in 18 and 20).

\section{TARGETS AND MECHANISMS OF METAL ACTION}

Metals may affect the male reproductive system directly, when they target specific reproductive organs, or indirectly, when they act on the neuroendocrine system.

These effects can be long lasting and irreversible if Sertoli cells are disrupted during foetal development. The number of Sertoli cells determines the number of sperm produced in adulthood, because each Sertoli cell can support only a finite number of germ cells that develop into sperm. According to Sharpe et al. (41), Sertoli cells proliferate during the foetal, neonatal and pre-pubertal period, and each of these periods is particularly sensitive to the adverse effects of metals.

The disruption of spermatogenesis in men (Table 1) at any stage of cell differentiation can decrease the total sperm count, increase the abnormal sperm count, impair the stability of sperm chromatin or damage sperm DNA (43). Accumulating in the epididimys, prostate, vesicular seminalis or seminal fluid, metals may impair progressive sperm motility (44). In addition, metals can cause hormonal imbalance by affecting the neuroendocrine system, disrupting the secretion of androgens from Leydig cells or Inhibin B from Sertoli cells (45).

There is growing evidence that oxidative stress is implicated in the pathogenesis of male infertility (19, 
46-50). It is known that human spermatozoa are particularly vulnerable to oxidative stress. An excessive generation of reactive oxygen species (ROS) in the spermatozoa results in the peroxidation of polyunsaturated fatty acids within their plasma membrane (51). Several metals, including iron, copper, nickel, lead, and cadmium, may increase ROS production, decrease glutathione and other antioxidant levels, enhance the lipid peroxidation of the cell membrane, cause apoptosis, and contribute to the oxidative damage of DNA (52-55). Damage to the sperm membrane reduces sperm's motility and ability to fuse with the oocyte, whereas damage to sperm DNA compromises paternal genomic contribution to the embryo (49) and increases the risk of infertility, miscarriage, or serious disease in the offspring (56).

Some malformations of the male reproductive system, such as cryptorchidism, hypospadias, and prostate and testicular cancers may originate from exposure to endocrine disruptors (Table 1). Cadmium, mercury, lead, and arsenic are suspected to affect the endocrine system (58-59). Evidence is usually limited to animal data or to in vitro studies (59-61). The clinical and epidemiological findings are scarce and controversial, and often difficult to interpret because of multiple exposures to different agents and latency of effects.

\section{REPRODUCTIVE EFFECTS OF METAL EXPOSURE}

The assessment of male reproductive capacity usually includes the following reproductive parameters:

- parameters of semen quality (e.g. semen volume, sperm concentration and count, motility, viability, and morphology of sperm),

- parameters of the secretory function of the prostate and seminal vesicles in seminal plasma (e.g. zinc, fructose), and

- parameters of reproductive endocrine function in serum (i.e. sex hormones; e.g. follicle-stimulating hormone, luteinizing hormone, testosterone, and oestradiol).

Metals can affect the testis size, semen quality, the secretory function of the prostate and seminal vesicles, the reproductive endocrine function and can lead to the loss of fertility and libido or to impotence (18-22). Moreover, exposure to cadmium, lead, and inorganic arsenic may contribute to prostate cancer development (62-66). Environmental exposure to cadmium and/or lead is associated with increased serum prostate specific antigen (PSA, Table 1) (67-68). Most reports on detrimental influence of metals on reproductive health in men are from occupational studies with highlevels exposure (18-20).

\section{Effects of occupational exposure to metals on reproductive parameters}

In men occupationally exposed to lead, blood lead levels equal to or higher than $400 \mu \mathrm{g} \mathrm{L}^{-1}$ have been associated with reduced sperm count, poor semen motility, and abnormal sperm morphology, particularly of the sperm head (69-78). Effects on the reproductive endocrine function have been less consistent $(71,74$, 79-83). Reduced sperm count and concentration, and lower motility were found in lead workers with blood lead levels lower than $400 \mu \mathrm{g} \mathrm{L}^{-1}(78,84-85)$. These adverse effects of lead exposure were confirmed in regression models adjusted for the influence of age, smoking, alcohol, blood cadmium, and serum copper and zinc (78). In addition, a better correlation of reproductive parameters with the activity of deltaaminolevulinic acid dehydratase (ALAD) in blood, which better reflects long-term cumulative lead exposure than blood lead level, indicated that the reproductive effects were at least partly mediated through lead interference with zinc metabolism (78).

Information regarding reproductive effects in male workers occupationally exposed to cadmium is limited and insufficient to estimate a quantitative doseresponse relationship or no-adverse-effect exposure thresholds. For example, in smelter workers exposed to cadmium and control subjects, significantly higher serum testosterone was found in men with urinary cadmium levels of (10 to 20) $\mu \mathrm{g} \mathrm{g}^{-1}$ creatinine than in men with (0 to 2) $\mu \mathrm{g} \mathrm{g}^{-1}$ or (2 to 5) $\mu \mathrm{g} \mathrm{g}^{-1}$ creatinine (85). In men with urinary cadmium levels $>20 \mu \mathrm{g} \mathrm{g}^{-1}$ creatinine, serum levels of the luteinising hormone were significantly higher, but testosterone levels did not differ significantly. Other studies showed no significant reproductive effect of occupational exposure to cadmium (86-87).

A few studies reported the effects of occupational exposure to mercury, manganese, chromium and boron on reproductive health in men and the available data are inconsistent.

In chloralkali workers with mean urinary mercury of $27 \mu \mathrm{g} \mathrm{g}^{-1}$ creatinine and mean blood mercury of 9.5 
$\mu \mathrm{g} \mathrm{L} \mathrm{L}^{-1}$, exposed for an average of 10 years to mercury vapour, cumulative mercury exposure positively correlated with serum total testosterone, but not with free testosterone (88). In another group of workers with urinary mercury of $71.2 \mu \mathrm{g} \mathrm{g}^{-1}$ creatinine, no significant association was found between urinary mercury levels and the parameters of reproductive endocrine function (87).

Two reproductive epidemiological studies of male workers occupationally exposed to manganese also yielded contradictory results. Although impotence and lack of sexual desire was higher in the exposed than control group, no significant difference was found in other reproductive outcomes between the groups (89). In another group of workers, which consisted of miners, electric welders in mechanical fields and welders in shipbuilding, a significantly lower sperm count and percentage of total viable sperm was found comparing to control group. However, after adjusting for the influence of copper, nickel, chromium, and iron concentration in semen on the measured reproductive parameters, manganese was no longer a significant predictor of adverse reproductive effects $(90)$.

It was reported that workers exposed to chromium (VI) had significantly higher serum follicle stimulating hormone concentration and lower sperm concentration and motility, seminal plasma zinc levels, lactate dehydrogenase (LDH), and $\mathrm{LDH}_{-} \mathrm{C}_{4}(91)$, and significantly higher percentage of abnormal sperm then control workers, but other semen quality parameters did not differ between them (92). Blood chromium positively correlated with the percentage of abnormal sperm in the exposed workers (92). While one study of welders exposed to chromium (VI) reported a 67 $\%$ decrease in sperm concentration compared to controls and an inverse correlation between sperm concentration and blood chromium levels in the exposed workers (93), another study showed no significant difference in semen quality between welders and other workers (94).

As for boron, there is no clear evidence that occupational exposure impairs sperm concentration, motility, morphology, or DNA integrity (95-97).

No study was found on reproductive effects of occupational exposure to inorganic or organic arsenic in men.

Most of the above-mentioned occupational studies were cross-sectional in design, comparing measured parameters between the exposed and unexposed workers. The most studied metal is lead, whereas only a few occupational reproductive studies were found for mercury, manganese, chromium and boron, and none for arsenic. Some discrepant findings from these studies may be attributed to: different levels and duration of metal exposure, fluctuation in metal exposure levels, no control group or an inadequate control group, a small number of subjects examined, division of subject into categories, lack of relevant

Table 1 Reproductive health terminology

\begin{tabular}{ll}
\hline TERM & DEFINITION / EXPLANATION \\
\hline Spermatogenesis & $\begin{array}{l}\text { A cellular process that occurs in seminiferous tubules in the testis and that produces } \\
\text { mature male sex cells in ca. } 74 \text { days in humans (42); it starts at puberty and usually } \\
\text { continues until death. }\end{array}$ \\
\hline & $\begin{array}{l}\text { An exogenous agent that interferes with the synthesis, secretion, transport, binding, } \\
\text { action, or elimination of natural hormones in the body that is responsible for the } \\
\text { maintenance of homeostasis, reproduction, development and/or behaviour and is } \\
\text { able to alter the structure or function of the endocrine system and to cause adverse } \\
\text { effects on organisms or their progeny or (sub)populations (57). }\end{array}$ \\
\hline Cryptocrine disruptor & Undescended testicle. \\
\hline Hypospadias & $\begin{array}{l}\text { A birth defect of the urethra in the male that involves an abnormally placed urinary } \\
\text { meatus (opening), i.e. displacement of the urethral meatus from the tip to the ventral } \\
\text { side of the phallus. }\end{array}$ \\
\hline Prostate specific antigen & $\begin{array}{l}\text { A marker that in combination with digital rectal examination is used as an aid in the } \\
\text { detection of prostate cancer in men. }\end{array}$ \\
\hline Time to pregnancy (TTP) & $\begin{array}{l}\text { Time taken to conceive after the couple had stopped using contraceptives and } \\
\text { treatment for infertility; The TTP distribution in a population describes its fertility. }\end{array}$ \\
\hline
\end{tabular}


information on selection criteria and/or lack of control for other common factors capable of affecting metal concentration and reproductive parameters. Only a few studies were adjusted for age, smoking habits and alcohol consumption $(78,85)$, and concentration of other metals $(78,90)$.

\section{Effects of occupational exposure to metals on fertility}

Time to pregnancy (TTP, Table 1) is a frequently used biomarker of effect in occupational epidemiology. Since the unit of study is the couple, information about the potential confounding factors affecting both partners are required.

Several studies $(19,98)$ have indicated that paternal blood lead levels of approximately $300 \mu \mathrm{g} \mathrm{L}^{-1}$ to $400 \mu \mathrm{g} \mathrm{L}^{-1}$ are the "most likely threshold for increased rate of spontaneous abortions, reduced rate of live births, and prolonged TTP, although inconsistent findings or a minor incompatibility were also reported" (19). A longer TTP was associated with higher blood lead levels within the group of lead workers although shorter TTP was found in lead workers than in controls (98). Seminal plasma lead levels inversely correlated with the fertilising capacity expressed by mannose receptor expression, and fertilisation rate in patients seeking in vitro fertilisation (IVF) (99).

Lauwerys et al. (100) found no effect of occupational exposure to mercury on fertility assessed by the rate of live births, whereas two other studies reported a significant association between paternal occupational exposure to mercury vapour and higher spontaneous abortion rate (101-102).

The results of the only two studies evaluating the influence of paternal exposure to manganese dust on the rate of live births are controversial (100, 103).

Judging by the study of occupational exposure to boron as sodium borate at a large mining and production facility in California (104), paternal exposure does not seem to bear a greater risk for live births.

\section{Effects of environmental exposure to metals on reproductive parameters}

Several studies indicate that adverse reproductive effects of some metals can occur even at an exposure range that is common for general populations worldwide.
Low to moderate lead exposure has been associated with reduced sperm concentration, poor semen motility and viability, and abnormal sperm morphology (66, 105-108). Moreover, blood lead level $<150 \mu \mathrm{g}$ $\mathrm{L}^{-1}$ has been associated with higher serum levels of testosterone and oestradiol, and lower serum levels of prolactin (66). In men with median blood lead of $15 \mu \mathrm{g} \mathrm{L}^{-1}$, an inverse association with serum prolactin and thyroid stimulating hormone (107) was found, but there was no association between blood lead levels and sperm concentration, motility or morphology (109). A Mexican study in men showed a significant association between lower semen quality and lead in spermatozoa or seminal fluid, but not with blood lead (106). All of these studies have been adjusted for the influence of age and current smoking $(66,105-109)$, and for other metals $(66,105,107-109)$. Other studies (110-114) have not found any association between low-level lead exposure and semen quality or endocrine function in men.

Tobacco smoking significantly increases cadmium levels in blood and seminal plasma in occupationally unexposed men $(78,115-117)$ and may adversely affect the male reproductive function. Several studies have found evidence that low-level cadmium affects semen quality and/or reproductive hormone levels. The following effects have been reported in men with blood cadmium level $<1.5 \mu \mathrm{g} \mathrm{L}^{-1}$ : decreased sperm density and number of sperm per ejaculate (114), decreased semen volume $(114,118)$, and increased sperm midpiece defects and immature sperm forms (118). After adjusting for potential confounders, these effects included reduced testis size and higher serum levels of the follicle stimulating hormone, testosterone, and oestradiol (105). In men with median blood cadmium level of $0.20 \mu \mathrm{g} \mathrm{L}^{-1}$, a positive association between blood cadmium and inhibin B levels in a model adjusted for age, BMI, and current smoking or for other metals (119) was found, but there were no effects on semen parameters (109). Urinary cadmium showed no significant association with serum testosterone, follicle stimulating hormone, and luteinizing hormone levels after adjusting for potential confounders (67).

Several studies (120-122) have indicated that total mercury levels $>8 \mu \mathrm{g} \mathrm{L}^{-1}$ in blood or $>8 \mathrm{ng} \mathrm{L}^{-1}$ in seminal fluid are associated with lower sperm concentration and motility and higher abnormal sperm count. Median total mercury in blood of $1.10 \mu \mathrm{g} \mathrm{L}^{-1}$ has not been associated with parameters of semen quality or endocrine function $(109,123)$. An increased 
risk of subfertility was found to be associated with increasing levels of mercury in hair (124). Consumption of seafood can significantly increase methyl-mercury in blood, hair, and seminal fluid. However, blood methyl-mercury between $0.11 \mu \mathrm{g} \mathrm{L}-1$ and $16.59 \mu \mathrm{g}$ $\mathrm{L}^{-1}$ (median $2.25 \mu \mathrm{g} \mathrm{L}^{-1}$ ) in Swedish fishermen did not affect sperm concentration, count, motility, chromatin integrity, or the proportion of Y-chromosome bearing sperm (125).

Only one group of researchers have evaluated the influence of environmentally relevant levels of manganese on male reproductive ability. They found that blood manganese was significantly associated with low sperm concentration and motility $(123,126)$, higher inhibin B, and lower prolactin levels $(109,119)$, although adjusting for confounders produced slightly different results.

The same group of researchers has published results on reproductive toxicity of environmental arsenic in men. Blood arsenic levels higher than $5.8 \mu \mathrm{g} \mathrm{L}^{-1}$ were associated with low sperm motility after adjusting for smoking and age, although the dose response trend was not linear in all groups (109). In a model adjusted for other metals, arsenic was a significant risk factor for low semen volume. In the same group of subjects, blood arsenic increased the risk of low luteinizing hormone level after adjusting for age, BMI, and current smoking (119).

In a study of environmental chromium exposure, seminal chromium levels were not significantly different between fertile and infertile men (127). However, blood chromium was significantly associated with an increase in serum prolactin (107), and a non-linear decrease in serum inhibin B (119) after adjusting for age, BMI, and smoking status, or other metals in both studies.

There is no data regarding the reproductive effects of environmental exposure to boron in men.

With regard to environmental exposure to metals, most information on reproductive effects concern lead, cadmium, and mercury. Some of these studies have been well designed with a sufficient number of participants and appropriately adjusted for potential confounders. However, effects of smoking intensity and alcohol consumption are often not considered, although tobacco smoke and alcohol drinks may be an important source of non-occupational metal exposure. Moreover, smoking and/or alcohol itself may have some detrimental effects on reproductive health in men (128-131).

\section{REPRODUCTIVE EFFECTS OF EXPOSURE TO METALS AS NANOPARTICLES}

Humans have always been exposed to airborne nanoparticles in dust storms, volcanic ash, and other natural processes (132), but this exposure has recently dramatically increased due to the rapid advancement of nanotechnology. Several researchers have expressed concern about the possible adverse effects of nanoparticles on human health because of their ability to pass through biological membranes (132-134) and "translocate through the circulatory, lymphatic, and nervous systems to many tissues and organs" (132). Potential reproductive and developmental toxicity of manufactured nanomaterials was investigated in several experimental in vivo and in vitro studies reviewed by Ema et al. (135). It was found that "high concentrations of $\mathrm{TiO}_{2}$ nanoparticles affect the viability and proliferation of mouse Leydig cells, that gold nanoparticles reduced the motility of human sperm, that silver, aluminium, and molybdenum trioxide were toxic to mouse spermatogonia stem cells, that silica nanoparticles inhibited the differentiation of mouse embryonic stem cells and midbrain cells, respectively, and that cadmium selenium-core quantum dots inhibited pre- and postimplantation development of mouse embryos". There is no epidemiological study regarding the reproductive effects of nanoparticles.

\section{CONCLUDING REMARKS}

The overall results of this review provide evidence for adverse effects of lead on certain reproductive parameters, and cadmium on prostate impairment and serum testosterone levels, even at moderate to low exposure levels. It seems that mercury and manganese affect semen quality and serum hormone levels, although more studies are needed to confirm these results. Less consistent evidence indicates that arsenic and chromium might adversely affect the male reproductive system, whereas there is no clear evidence that boron exposure might do the same.

Most published studies report the effects of a single metal, although human exposure combines toxic and essential metals that can interact. Influence of other risk factors that can affect metal concentration and/or reproductive parameters in men is rarely considered. No epidemiological study assessing the reproductive 
effects of nanoparticles is available. There is insufficient data for establishing quantitative doseresponse relationships and no-adverse-effect exposure thresholds for metal-induced reproductive effects in men.

Only a few well-designed epidemiological studies have investigated combined exposure to metals and have been controlled for potential confounders.

Further research evaluating the effects of a particular metal on reproductive health in men should take into account the contribution of other metals, agents, and the lifestyle. A combined analysis could provide useful information about individual health risk.

\section{Acknowledgement}

This research was supported by the Croatian Ministry of Science, Education and Sports (grant no. 022-0222411-2408).

\section{REFERENCES}

1. Carlsen E, Giwereman A, Keiding N, Skakkebaek NE. Evidence for decreasing sperm quality of semen during the past 50 years. Br Med J 1992;304:609-13.

2. Adami HO, Bergström R, Möhner M, Zatoński W, Storm H, Ekbom A, Tretli S, Teppo L, Ziegler H, Rahu M, Gurevicius R, Stengrevics A. Testicular cancer in nine northern European countries. Int J Cancer 1994;59:33-8.

3. Carlsen E, Giwercman A, Keiding N, Skakkebaek NE. Declining semen quality and increasing incidence of testicular cancer: is there a common cause? Environ Health Perspect 1995;103(Suppl 7):137-9.

4. Richiardi L, Bellocco R, Adami HO, Torrång A, Barlow L, Hakulinen T, Rahu M, Stengrevics A, Storm H, Tretli S, Kurtinaitis J, Tyczynski JE, Akre O. Testicular cancer incidence in eight northern European countries: secular and recent trends. Cancer Epidemiol Biomarkers Prev 2004;13:2157-66.

5. Skakkebaek NE, Rajpert-De Meyts E, Main KM. Testicular dysgenesis syndrome: an increasingly common developmental disorder with environmental aspects. Hum Reprod 2001;16:972-8.

6. Swan SH, Elkin EP, Fenster L. The question of declining sperm density revisited: An analysis of 101 studies published 1934-1996. Environ Health Perspect 2000;108:961-6.

7. Zheng Y, Bonde JP, Ernst E, Mortensen JT, Egense J. Is semen quality related to the year of birth among Danish infertility clients? Int J Epidemiol 1997:26:1289-97.

8. Saradha B, Mathu PP. Effect of environmental contaminants on male reproduction. Environ Toxicol Pharmacol 2006;21:3441.

9. Agarwal A, Desai NR, Ruffoli R, Carpi A. Lifestyle and testicular dysfunction: A brief update. Biomed Pharmacother 2008;62:550-3
10. Phillips KP, Tanphaichitr N. Human exposue to endocrine disrupters and semen quality. J Toxicol Environ Health B 2008; $11: 188-220$

11. Jurewicz J, Hanke W, Radwan M, Bonde JP. Environmental factors and semen quality. Int J Occup Med Environ Health 2009;22:305-29.

12. Mendiola J, Torres-Cantero AM, Agarwal A. Lifestyle factors and male infertility: an evidence-based review. Arch Med Sci 2009;5(1A):S3-12.

13. Wong EW, Cheng CY. Impacts of environmental toxicants on male reproductive dysfunction. Trends Pharmacol Sci 2011;32:290-9.

14. Agency for Toxic Substances and Disease Registry (ATSDR). Public Health Statement for Cadmium, September 2008 [displayed 3 January 2012]. Available at http://www.atsdr. cdc. .gov/phs $/$ phs. asp?id=46\&tid= 15

15. Tariba B. Metals in wine-impact on wine quality and health outcomes. Biol Trace Elem Res 2011;144:143-56.

16. Tariba B, Pizent A, Kljaković-Gašpić Z. Determination of lead in Croatian wines by graphite furnace atomic absorption spectrometry. Arh Hig Rada Toksikol 2011;62:25-31.

17. Tariba B, Kljaković-Gašpić Z, Pizent A. Estimation of copper intake in moderate wine consumers in Croatia. Arh Hig Rada Toksikol 2011;62:229-34.

18. Benoff S, Jacob A, Hurley IR. Male infertility and environmental exposure to lead and cadmium. Hum Reprod Update 2000;6:107-21.

19. Apostoli P, Telišman S, Sager PR. Reproductive and developmental toxicity of metals. In: Nordberg GF, Fowler BA, Nordberg M, Friberg LT, editors. Handbook on the Toxicology of Metals. Amsterdam: Academic Press Elsevier; 2007. p. 213-49.

20. Wirth JJ, Mijal RS. Adverse effects of low level heavy metal exposure on male reproductive function. Syst Biol Reprod Med 2010;56:147-67.

21. Apostoli P, Kiss P, Porru S, Bonde JP, Vanhoorne M; ASCLEPIOS Study Group. Male reproductive toxicity of lead in animals and humans. Occup Environ Med 1998;55:36474.

22. Apostoli P, Catalani S. Metal ions affecting reproduction and development. Met Ions Life Sci 2011;8:263-303.

23. Agency for Toxic Substances and Disease Registry. Atlanta (ATSDR). Toxicological profile for arsenic 2007 [displayed 3 January 2012] Available at http://www.atsdr.cdc.gov/ ToxProfiles/tp2.pdf

24. Agency for Toxic Substances and Disease Registry (ATSDR). Toxicological profile for boron 2010 [displayed 3 January 2012] Available at http://www.atsdr.cdc.gov/ToxProfiles/ tp26.pdf

25. Agency for Toxic Substances and Disease Registry (ATSDR). Draft Toxicological profile for cadmium 2008 [displayed 3 January 2012] Available at http://www.atsdr.cdc.gov/ ToxProfiles/tp5.pdf

26. Agency for Toxic Substances and Disease Registry (ATSDR). Draft Toxicological profile for chromium 2008 [displayed 3 January 2012] Available at http://www.atsdr.cdc.gov/ ToxProfiles/tp7.pdf

27. Agency for Toxic Substances and Disease Registry (ATSDR). Toxicological profile for lead 2007 [displayed 3 January 2012] Available at http://www.atsdr.cdc.gov/toxprofiles/tp13. pdf

28. Agency for Toxic Substances and Disease Registry (ATSDR). Draft Toxicological profile for manganese 2008 [displayed 
3 January 2012] Available at http://www.atsdr.cdc.gov/ toxprofiles/tp151.pdf

29. Agency for Toxic Substances and Disease Registry (ATSDR). Toxicological profile for mercury 1999 [displayed 3 January 2012] Available at http://www.atsdr.cdc.gov/toxprofiles/tp46. html

30. Prpić-Majić D, Pizent A, Jurasović J, Pongračić J, RestekSamaržija N. Lead poisoning associated with the use of Ayurvedic metal-mineral tonics. Clin Toxicol 1996;34:41723.

31. Gogtay NJ, Bhatt HA, Dalvi SS, Kshiragar NA. The use and safety on nonallopathic Indian medicines. Drug Saf 2002;25:1005-9.

32. Thomas KJ, Coleman P, Nicholl JP. Trends in access to complementary or alternative medicines via primary care in England: 1995-2001 results of a follow-up national survey. Fam Pract 2003;20:575-7.

33. Bryant SD. Lead-contaminated drinking waters in the public schools of Philadelphia. J Toxicol Clin Toxicol 2004;42:28794.

34. Fowler BA. Monitoring of human populations for early markers of cadmium toxicity: A review. Toxicol Appl Pharmacol 2009;238:294-300.

35. Ćavar S, Klapec T, Jurišić Grubešić R, Valek M. High exposure to arsenic from drinking water at several localities in eastern Croatia. Sci Total Environ 2005;339:277-82.

36. Telišman S. Interactions of essential and/or toxic metals and metalloid regarding interindividual differences in susceptibility to various toxicants and chronic diseases in men. Arh Hig Rada Toksikol 1995;46:459-76.

37. Piasek M, Mikolić A. Minerals and physiology (From essentiality to toxicity: a review of important minerals and their major impact on the human body's physiology). In: Gašperlin L, Žlender B, editors. Role of Minerals in Food Technology and Nutrition. Ljubljana: Biotehniška fakulteta, Oddelek za živilstvo and Slovensko prehransko društvo; 2009. p. 9-19.

38. Pizent A, Jurasović J, Telišman S. Serum calcium, zinc, and copper in relation to biomarkers of lead and cadmium in men. J Trace Elements Med Biol 2003;17:199-205.

39. Lazarus M. Međudjelovanje kadmija i selenija u sisavaca [Cadmium and selenium interaction in mammals, in Croatian]. Arh Hig Rada Toksikol 2010;61:357-69.

40. Matović V, Buha A, Bulat Z, Dukić-Ćosić D. Cadmium toxicity revisited: focus on oxidative stress induction and interactions with zinc and magnesium. Arh Hig Rada Toksikol. 2011;62:65-76.

41. Sharpe RM, McKinnell C, Kivlin C, Fisher JS. Proliferation and functional maturation of Sertoli cells, and their relevance to disorders of testis function in adulthood. Reproduction 2003;125:769-84.

42. Amann RP. The cycle of the seminiferous epithelium in humans: A need to revisit? J Androl 2008;29:469-87.

43. Mangelsdorf I, Buschmann J, Orthen B. Some aspects relating to the evaluation of the effects of chemicals on male fertility. Regul Toxicol Pharmacol 2003;37:356-69.

44. Hess RA. Effects of environmental toxicants on the efferent ducts, epididymis and fertility. J Reprod Fertil Suppl 1998;53:247-59.

45. Jensen TK, Bonde JP, Joffe M. The influence of occupational exposure on male reproductive function. Occup Med 2006;56:544-53.
46. Aitken RJ. A free radical theory of male infertility. Reprod Fertil Dev 1994;6:19-23.

47. Sanocka D, Miesel R, Jedrzejczak P, Kurpisz MK. Oxidative stress and male infertility. J Androl 1996;17:449-54.

48. Garrido N, Meseguer M, Simon C, Pellicer A, Remohi J. Pro-oxidative and anti-oxidative imbalance in human semen and its relation with male fertility. Asian J Androl 2004;6:59-65.

49. Tremellen K. Oxidative stress and male infertility - a clinical perspective. Hum Reprod Update 2008;14:243-58.

50. Makker K, Agarwal A, Sharma R. Oxidative stress and male infertility. Indian J Med Res 2009;129:357-67.

51. Koppers AJ, De Iuliis GN, Finnie JM, McLaughlin EA, Aitken RJ. Significance of mitochondrial reactive oxygen species in the generation of oxidative stress in spermatozoa. J Clin Endocrinol Metab 2008;93:3199-207.

52. Jones R, Mann T, Sherins RJ. Peroxidative breakdown of phospholipids in human spermatozoa: spermicidal effects of fatty acid peroxides and protective action of seminal plasma Fertil Steril 1979;31:531-7.

53. Aitken RJ, Harkiss D, Buckingham D. Relationship between iron-catalysed lipid peroxidation potential and human sperm function. J Reprod Fertil 1993;98:257-65.

54. Liang R, Senturker S, Shi X, Bal W, Dizdaroglu M, Kasprzak $\mathrm{KS}$. Effects of $\mathrm{Ni}$ (II) and $\mathrm{Cu}$ (II) on DNA interaction with the $\mathrm{N}$-terminal sequence of human protamine $\mathrm{P} 2$ : enhancement of binding and mediation of oxidative DNA. Carcinogenesis 1999;20:893-8.

55. Wellejus A, Poulsen HE, Loft S. Iron-induced oxidative DNA damage in rat sperm cells in vivo and in vitro. Free Radical Res 2000;32:75-83.

56. Aitken JR, Koppers AJ. Apoptosis and DNA damage in human spermatozoa. Asian J Androl 2011;13:36-42.

57. World Health Organization (WHO). Global assessment of the state-of-the-science of endocrine disruptors. Geneva: WHO; 2002.

58. Chedrese PJ, Piasek M, Henson MC. Cadmium as an endocrine disruptor in the reproductive system. Immunol Endocr Metab Agents Med Chem 2006;6:27-35.

59. Iavicoli I, Fontana L, Bergamaschi A. The effects of metals as endocrine disruptors. J Toxicol Environ Health B Crit Rev 2009;12:206-23.

60. Takiguchi M, Yoshihara S. New aspects of cadmium as endocrine disruptor. Environ Sci 2006;13:107-16.

61. Siu ER, Mruk DD, Porto CS, Cheng CY. Cadmium-induced testicular injury. Toxicol Appl Pharmacol 2009;238:240-9.

62. Chen CJ, Kuo TL, Wu MM. Arsenic and cancers. Lancet 1988;1:414-5

63. Chen CJ, Wang CJ. Ecological correlation between arsenic levels in well water and age adjusted mortality from malignant neoplasms. Cancer Res 1990;50:5470-4.

64. Goyer RA, Liu J, Waalkes MP. Cadmium and cancer of prostate and testis. BioMetals 2004;17:555-8.

65. Benbrahim-Tallaa L, Waalkes MP. Inorganic arsenic and human prostate cancer. Environ Health Perspect 2008;116:158-64.

66. Telišman S, Čolak B, Pizent A, Jurasović J, Cvitković P. Reproductive toxicity of low-level lead exposure in men. Environ Res 2007;105:256-66.

67. Zeng X, Jin T, Jiang X, Kong Q, Ye T, Nordberg GF. Effects on the prostate of environmental cadmium exposure - a cross-sectional population study in China. BioMetals 2004; 17:559-65. 
68. Pizent A, Čolak B, Kljaković-Gašpić Z, Telišman S. Prostatespecific antigen (PSA) in serum in relation to blood lead concentration and alcohol consumption. Arh Hig Rada 2009;60:69-78

69. Alexander BH, Checkoway H, Van Netten C, Kaufman JD, Vaughan TL, Mueller BA, Faustman EM. Paternal Occupational Lead Exposure and Pregnancy Outcome. Int J Occup Environ Health 1996;2:280-5.

70. Alexander BH, Checkoway H, Faustman EM, van Netten C, Muller CH, Ewers TG. Contrasting associations of blood and semen lead concentrations with semen quality among lead smelter workers. Am J Ind Med 1998;34:464-9.

71. Assenato G, Paci C, Baser ME Molinini R, Candela RG, Altamura BM, Giorgino R. Sperm count supression without endocrine dysfunction in lead-exposed men. Arch Environ Health 1987:42:124-7.

72. Cullen MR, Kayne RD, Robins JM. Endocrine and reproductive dysfunction in men associated with occupational inorganic lead intoxication. Arch Environ Health 1984;39:43140.

73. Eibensteiner L, Del Carpio Sanz A, Frumkin H, Gonzales $\mathrm{C}$, Gonzales GF. Lead exposure and semen quality among traffic police in Arequipa, Peru. Int J Occup Environ Health 2005;11:161-6.

74. Gennart JP, Bernard A, Lauwerys R. Assessment of thyroid, testes, kidney and autonomic nervous system function in lead exposed workers. Int Arch Occup Environ Health 1992;64:4957.

75. Hu W, Wu SH, Wang LL, Wang GI, Fan H, Liu ZM. A toxicological and epidemiological study on reproductive functions of male workers exposed to lead. J Hyg Epidemiol Microbiol Immunol 1992;36:25-30.

76. Lerda D. Study of sperm characteristics in persons occupationally exposed to lead. Am J Ind Med 1992;22:56771.

77. Robins TG, Bornman MS, Ehrlich RI, Cantrell AC, Pienaar E, Vallabh J, Miller S. Semen quality and fertility of men employed in a South African lead acid battery plant. Am J Ind Med 1997;32:369-76.

78. Telišman S, Cvitković P, Jurasović J, Pizent A, Gavella M, Ročić B. Semen quality and reproductive endocrine function in relation to biomarkers of lead, cadmium, zinc, and copper in men. Environ Health Perspect 2000;108:45-53.

79. Erfurth EM, Gerhardsson L, Nilsson A, Rylander L, Schütz A, Skerfving S, Börjesson J. Effects of lead on the endocrine system in lead smelter workers. Arch Environ Health 2001;56:449-55.

80. Gustafson A, Hedner P, Schutz A, Skerfving S. Occupational lead exposure and pituitary function. Int Arch Occup Environ Health 1989;61:277-81.

81. McGregor AJ, Mason HJ. Chronic occupational lead exposure and testicular endocrine function. Human Exp Toxicol 1990;9:371-6.

82. Ng TP, Goh HH, Ng YL, Ong HY, Ong CN, Chia KS, Chia $\mathrm{SE}$, Jeyaratnam J. Male endocrine functions in workers with moderate exposure to lead. Br J Ind Med 1991;48:485-91.

83. Rodamilans M, Osaba MJM, To-Figueras J, Rivera Fillat F, Ma Marques J, Pérez P, Corbella J. Lead toxicity on endocrine testicular function in an occupational exposed population. Hum Toxicol 1988;7:125-8.

84. Alexander BH, Checkoway H, van Netten C, Muller CH, Ewers TG, Kaufman JD, Mueller BA, Vaughan TL, Faustman
EM. Semen quality of men employed at a lead smelter. Occup Environ Med 1996;53:411-6.

85. Zeng X, Lin T, Zhou Y, Kong Q. Alterations of serum hormone levels in male workers occupationally exposed to cadmium. J Toxicol Environ Health A 2002;65:513-21.

86. Mason HJ. Occupational cadmium exposure and testicular endocrine function. Hum Exp Toxicol 1990;9:91-4.

87. McGregor AJ, Mason HJ. The effects of occupational exposure to cadmium, lead and mercury vapour on male reproductive endocrine function. In: Farmer JG, editor. Heavy Metals in the Environment. Edinburgh: CEP Consultants; 1991. p. 375-8.

88. Barregård L, Lindstedt G, Schütz A, Sällsten G. Endocrine function in mercury exposed chloralkali workers. Occup Environ Med 1994;51:536-40.

89. Jiang Y, Lu J, Xie P, et al. [Effects of manganese on the sexual function and reproductive outcome of male exposed workers, in Chinese]. Chi J Ind Hyg Occup Dis 1996;14:271-3.

90. Wu W, Zhang Y, Zhang F, et al. [Studies on the semen quality in workers exposed to manganese and electric welding, in Chinese]. Chin J Prev Med 1996;30:266-8.

91. Li H, Chen Q, Li S, Yao W, Li L, Shi X, Wang L, Castranova V, Vallyathan V, Ernst E, Chen C. Effect of Cr(VI) exposure on sperm quality; human and animal studies. Ann Occup Hyg 2001;45:505-11.

92. Kumar S, Sathwara NG, Gautam AK, Agarwal K, Shah B, Kulkarni PK, Patel K, Patel A, Dave LM, Parikh DJ, Saiyed $\mathrm{HN}$. Semen quality of industrial workers occupationally exposed to chromium. J Occup Health 2005;47:424-30.

93. Dandevi K, Rozati R, Reddy PP, Grover P. Semen quality of Indian welders occupationally exposed to nickel and chromium. Reprod Toxicol 2003;17:451-6.

94. Bonde JP, Ernst E. Sex hormones and semen quality in welders exposed to hexavalent chromium. Hum Exp Toxicol 1992;11:259-63.

95. Robbins WA, Xun L, Jia J, Kennedy N, Elashoff DA, Ping L. Chronic boron exposure and human semen parameters. Reprod Toxicol 2010;29:184-90.

96. Korkmaz M, Yenigün M, Bakirdere S, Ataman OY, Keskin S, Müezzinoğlu T, Lekili M. Effects of chronic boron exposure on semen profile. Biol Trace Elem Res 2011;143:738-50.

97. Scialli AR, Bonde JP, Brueske-Hohlfeld I, Culver BD, Li Y, Sullivan FM. An overview of male reproductive studies of boron with an emphasis on studies of highly exposed Chinese workers. Reprod Toxicol 2010;29:10-24.

98. Apostoli P, Bellini A, Porru S, Bisanti L. The effect of lead on male fertility: a time to pregnancy (TTP) study. Am J Ind Med 2000;38:310-15.

99. Benoff S, Centola GM, Millan C, Napolitano B, Marmar JL, Hurley IR. Increased seminal plasma lead levels adversely affect the fertility potential of sperm in IVF. Hum Reprod 2003;18:374-83.

100. Lauwerys R, Roels H, Genet P, Toussaint G, Bouckaert A, De Cooman S. Fertility of male workers exposed to mercury vapor or to manganese dust: a questionnaire study 10. Am J Ind Med 1985;7:171-6.

101. Alcser KH, Brix KA, Fine LJ, Kallenbach LR, Wolfe RA. Occupational mercury exposure and male reproductive health. Am J Ind Med 1989;15:517-29. 
102. Cordier S, Deplan F, Mandereau L, Hemon D. Paternal exposure to mercury and spontaneous abortions. Br J Ind Med 1991;48:375-81.

103. Gennart JP, Buchet JP, Roels H. Fertility of male workers exposed to cadmium, lead, or manganese. Am J Epidemiol 1992;135:1208-19.

104. Whorton MD, Haas JL, Trent L, Wong O. Reproductive effects of sodium borates on male employees: birth rate assessment. Occup Environ Med 1994;51:761-7.

105. Jurasović J, Cvitković P, Pizent A, Čolak B, Telišman S. Semen quality and reproductive endocrine function with regard to blood cadmium in Croatian male subject. BioMetals 2004;17:735-43.

106. Hernández-Ochoa I, García-Vargas G, López-Carrillo L, Rubio-Andrade M, Morán-Martínez J, Cebrián ME, Quintanilla-Vega B. Low lead environmental exposure alters semen quality and sperm chromatin condensation in northern Mexico. Reprod Toxicol 2005;20:221-8.

107. Meeker JD, Rossano MG, Protas B, Diamond MP, Puscheck E, Daly D, Paneth N, Wirth JJ. Multiple metals predict prolactin and thyrotropin (TSH) levels in men. Environ Res 2009;109:869-73.

108. Pant N, Upadhyay G, Pandey S, Mathur N, Saxena DK, Srivastava SP. Lead and cadmium concentration in the seminal plasma of men in the general population: correlation with sperm quality. Reprod Toxicol 2003;17:447-50.

109. Meeker JD, Rossano MG, Protas B, Diamond MP, Puscheck E, Daly D, Paneth N, Wirth JJ. Cadmium, lead, and other metals in relation to semen quality: human evidence for molybdenum as a male reproductive toxicant. Environ Health Perspect 2008;116:1473-9.

110. Butrimovitz GP, Sharlip I, Lo R. Extremely low seminal lead concentrations and male fertility. Clin Chim Acta 1983;135:229-31.

111. Hovatta O, Venäläinen ER, Kuusimäki L, Heikkilä J, Hirvi T, Reima I. Aluminium, lead and cadmium concentrations in seminal plasma and spermatozoa, and semen quality in Finnish men. Hum Reprod 1998;13:115-9.

112. Mendiola J, Moreno JM, Roca M, Vergara-Juárez N, Martínez-García MJ, García-Sánchez A, Elvira-Rendueles B, Moreno-Grau S, López-Espín JJ, Ten J, Bernabeu R, Torres-Cantero AM. Relationships between heavy metal concentrations in three different body fluids and male reproductive parameters: a pilot study. Environ Health 2011;10:6.

113. Noack-Fuller G, De Beer C, Seibert H. Cadmium, lead, selenium and zinc in semen of occupationally unexposed men. Andrologia 1993;25:7-12.

114. Xu B, Chia SE, Tsakok M, Ong CN. Trace elements in blood and seminal plasma and their relationship to sperm quality. Reprod Toxicol 1993;7:613-8.

115. Chia SE, Xu B, Ong CN, Tsakok FMH, Lee ST. Effect of cadmium and cigarette smoking on human semen quality. Int J Fertil Menopausal Stud 1994;39:292-8.

116. Telišman S, Jurasović J, Pizent A, Cvitković P. Cadmium in the blood and seminal fluid of nonoccupationally exposed adult male subjects with regard to smoking habits. Int Arch Occup Environ Health 1997;70:243-8.

117. Telišman S, Pizent A, Jurasović J, Cvitković P. Lead effect on blood pressure in moderately lead-exposed male workers. Am J Ind Med 2004;45:446-54.

118. Chia SE, Ong CN, Lee ST, Tsakok FH. Blood concentrations of lead, cadmium, mercury, zinc and copper and human semen parameters. Arch Androl 1992;29:177-83.

119. Meeker JD, Rossano MG, Protas B, Padmanahban V, Diamond MP, Puscheck E, Daly D, Paneth N, Wirth JJ.
Environmental exposure to metals and male reproductive hormones: circulating testosterone is inversely associated with blood molibdenum. Fertil Steril 2010;93:130-40.

120. Leung TY, Choy CM, Yim SF, Lam CW, Haines CJ. Whole blood mercury concentrations in sub-fertile men in Hong Kong. Aust N Z J Obstet Gynaecol 2001;41:75-7.

121. Choy CM, Lam CW, Cheung LT, Briton-Jones CM, Cheung LP, Haines CJ. Infertility, blood mercury concentrations and dietary seafood consumption: a case-control study. BJOG 2002;109:1121-5.

122. Choy CM, Yeung QS, Briton-Jones CM, Cheung CK, Lam $\mathrm{CW}$, Haines CJ. Relationship between semen parameters and mercury concentrations in blood and in seminal fluid from subfertile males in Hong Kong. Fertil Steril 2002;78:426-8.

123. Ramamoorthi RV, Rossano MG, Paneth N, Gardiner JC, Diamond MP, Puscheck E, Daly DC, Potter RC, Wirth JJ. An application of multivariate ranks to assess effects from combining factors: metal exposures and semen analysis outcomes. Stat Med 2008;27:3503-14.

124. Dickman MD, Leung CK, Leong MK. Hong Kong male subfertility links to mercury in human hair and fish. Sci Total Environ 1998;214:165-74.

125. Rignell-Hydbom A, Axmon A, Lundh T, Jönsson BA, Tiido T, Spano M. Dietary exposure to methyl mercury and PCB and the associations with semen parameters among Swedish fishermen. Environ Health 2007;6:14.

126. Wirth JJ, Rossano MG, Daly DC, Paneth N, Puscheck E, Potter RC, Diamond MP. Ambient manganese exposure is negatively associated with human sperm motiity and concentration. Epidemiology 2007;18:270-3.

127. Umeyama T, Ishikawa H, Takeshima H, Yoshii S, Koiso K. A comparative study of seminal trace elements in fertile and infertile men. Fertil Steril 1986;46:494-9.

128. Vine MF. Smoking and male reproduction: a review. Int J Androl 1996;19:323-37.

129. Platz EA, Leitzmann MF, Rimm EB, Willett WC, Giovannucci E. Alcohol intake, drinking patterns, and risk of prostate cancer in a large prospective cohort study. Am J Epidemiol 2004; 159:444-53.

130. Piasek M, Henson MC, Blanuša M, Kostial K. Assessment of steroid disruption and metal concentrations in human placenta: Effects of cigarette smoking. In: Fong CB, editor. Smoking and Health Research Frontiers. New York (NY): Nova Science Publishers, Inc.; 2007. p. 119-61.

131. Viloria T, Meseguer M, Martinez-Conejero JA, O'Connor JE, Remohi J, Pellicer A, Garrido N. Cigarette smoking affects specific sperm oxidative defenses but does not cause oxidative DNA damage. Fertil Steril 2010;94:631-7.

132. Buzea C, Pacheco II, Robbie K. Nanomaterials and nanoparticles: sources and toxicity. Biointerphases 2007;2: MR17-71.

133. Brooking J, Davis SS, Illum L. Transport of nanoparticles across the rat nasal mucosa. J Drug Target 2001;9:26779.

134. Wang J, Liu Y, Jiao F, Lao F, Li W, Gu Y, Li Y, Ge C, Zhou G, Li B, Zhao Y, Chai Z, Chen C. Time-dependent translocation and potential impairment on central nervous system by intranasally instilled $\mathrm{TiO} 2$ nanoparticles. Toxicology 2008;254:82-90.

135. Ema M, Kobayashi N, Naya M, Hanai S, Nakanishi J. Reproductive and developmental toxicity studies of manufactured nanomaterials. Reprod Toxicol 2010;30:34352. 


\section{Sažetak}

\section{UTJECAJ TOKSIČNOSTI METALA NA REPRODUKCIJSKU FUNKCIJU U MUŠKARACA}

Postoje indikacije da kombinacija genetskih, okolišnih i čimbenika načina života pridonosi uočenom poremećaju reprodukcijskog zdravlja u muškaraca. Metali su široko rasprostranjeni u čovjekovu okolišu te u hrani, vodi, zraku, cigaretnom dimu i alkoholnim pićima. Rezultati eksperimentalnih istraživanja sugeriraju štetne učinke većine ispitivanih metala na mušku reprodukcijsku funkciju. Međutim, odgovarajuća su istraživanja u ljudi oskudna. Ovaj rad sažima rezultate dosadašnjih epidemioloških istraživanja o učincima izloženosti metalima na mušku reprodukcijsku funkciju. Poseban naglasak dan je istraživanjima koja su razmatrala utjecaj istodobne izloženosti različitim metalima uz čimbenike čovjekova načina života i njihovo međudjelovanje na reprodukcijske učinke. Objavljeni rezultati daju dovoljno dokaza o štetnom djelovanju olova na neke reprodukcijske parametre te kadmija na poremećaj prostate i razinu testosterona u serumu, čak u uvjetima umjerene do niske razine izloženosti. Manje je dokaza o štetnom djelovanju na kvalitetu sjemena i razinu spolnih hormona nađeno za mangan. Podaci koji upućuju na moguće štetno djelovanje žive, arsena ili kroma nisu dosljedni, dok o štetnom djelovanju bora na mušku reprodukcijsku funkciju nema jasnih podataka. Utjecaj potencijalno uzročnih varijabli uzet je u obzir samo u nekoliko radova. Stoga buduća istraživanja poremećaja reprodukcijskog zdravlja u muškaraca trebaju razmatrati doprinos istovremene izloženosti različitim metalima koji u kombinaciji s ostalim čimbenicima mogu utjecati na osobnu (pre)osjetljivost.

KLJUČNE RIJEČI: kvaliteta sjemena u ljudi, metali, metaloidi, međudjelovanje metala, spolni hormoni

\section{CORRESPONDING AUTHOR:}

Alica Pizent

Institute for Medical Research and Occupational Health

Ksaverska cesta 2, HR-10000 Zagreb, Croatia

E-mail:apizent@imi.hr 